\title{
Microwave-assisted generation and reactivity of aza- and diazafulvenium methides: heterocycles via pericyclic reactions
}

\author{
Maria I. L. Soares, Teresa M. V. D. Pinho e Melo* \\ Department of Chemistry, University of Coimbra, 3004-535 Coimbra, Portugal
}

\section{A R T I C L E I N F O}

\section{Article history:}

Received 4 April 2008

Revised 30 May 2008

Accepted 2 June 2008

Available online $\mathrm{xxxx}$

\section{Keywords:}

Azafulvenium methide

Diazafulvenium methide

Pyrrole

Pyrazole

Sigmatropic $[1,8] \mathrm{H}$ shifts

1,7-Electrocyclization

$[8 \pi+2 \pi]$ Cycloaddition

\begin{abstract}
A B S T R A C T
Azafulvenium methides and diazafulvenium methides have been generated under microwave irradiation from 2,2-dioxo-1H,3H-pyrrolo[1,2-c]thiazoles and 2,2-dioxo-1H,3H-pyrazolo[1,5-c]thiazoles, respectively. Pericyclic reactions of these 1,7-dipole intermediates, namely, sigmatropic [1,8]H shifts, 1,7-electrocyclization or $[8 \pi+2 \pi]$ cycloaddition led to the synthesis of a range of pyrrole and pyrazole derivatives. The first evidence for the azafulvenium methides by intermolecular trapping via $[8 \pi+2 \pi]$ cycloaddition is reported.
\end{abstract}

(c) 2008 Elsevier Ltd. All rights reserved.
The study of pericyclic reactions of extended dipoles, such as azafulvenium methides 2 and diazafulvenium methides $\mathbf{4}$, is one of our current research interests (Scheme 1). ${ }^{1,2}$ It has been previously demonstrated that azafulvenium methides can be generated from 2,2-dioxo-1H,3H-pyrrolo[1,2-c]thiazoles under Flash Vacuum Pyrolysis ${ }^{1,3}$ or in some cases via sealed tube thermolysis. ${ }^{1}$ These dipoles participate in pericyclic reactions, namely, sigmatropic $[1,8] \mathrm{H}$ shifts and 1,7-electrocyclization, giving $N$-vinyl- or $C$-vinylpyrroles. The $\mathrm{SO}_{2}$ extrusion of 2,2-dioxo- $1 \mathrm{H}, 3 \mathrm{H}$-pyrazolo[1,5-c]thiazoles occurs more readily than from the analogous pyrrolo sulfones and can be carried out in refluxing 1,2,4-trichlorobenzene. ${ }^{2,3} 1$-Methyland 7,7-dimethyl-diazafulvenium methides undergo intramolecular sigmatropic $[1,8] \mathrm{H}$ shifts giving vinylpyrazoles. Diazafulvenium methides unsubstituted at C-7 participate in $[8 \pi+2 \pi]$ cycloadditions giving pyrazolo[1,5-a]pyridine derivatives resulting from the addition across the 1,7-position. However, generation of azafulvenium methides in the presence of dipolarophiles did not lead to the synthesis of $[8 \pi+2 \pi]$ cycloadducts. ${ }^{1 \mathrm{a}, 3}$

The synthetic utility of the use of microwave irradiation in organic synthesis has increased considerably in recent years. ${ }^{4}$ This nonconventional energy source is able to reduce chemical reaction times, increase yields and in some cases can lead to a different outcome when compared to conventional heating. In this context we decide to evaluate the potential of microwave irradiation to gener-

\footnotetext{
* Corresponding author. Tel.: +351 239 854475; fax: +351 239826068

E-mail address: tmelo@ci.uc.pt (T. M. V. D. Pinho e Melo).
}

ate aza- and diazafulvenium methides. In this Letter, we report that aza- and diazafulvenium methides can in fact be generated under microwave irradiation and we describe their reactivity including the first evidence for the azafulvenium methides by intermolecular trapping via $[8 \pi+2 \pi]$ cycloaddition.

Starting from 3-methyl-2,2-dioxo-1H,3H-pyrrolo[1,2-c]thiazoles $\mathbf{5 a}$ or $\mathbf{5 b}$ the reaction carried out in 1,2,4-trichlorobenzene under microwave irradiation afforded the corresponding $\mathrm{N}$-vinylpyrroles 7 (Scheme 2). The synthesis of these heterocyles results from the $\mathrm{SO}_{2}$ extrusion of sulfones $\mathbf{5}$ giving azafulvenium methides $\mathbf{6}$ followed by a sigmatropic [1,8]H shift. Azafulvenium methide $\mathbf{9}$

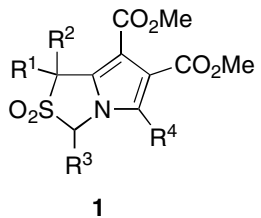

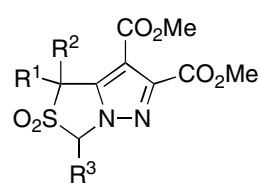
3
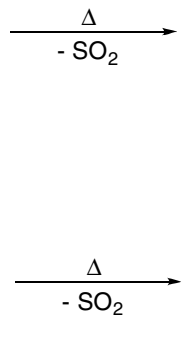<smiles></smiles><smiles></smiles>

4

0040-4039/\$ - see front matter (c) 2008 Elsevier Ltd. All rights reserved. doi:10.1016/j.tetlet.2008.06.013 


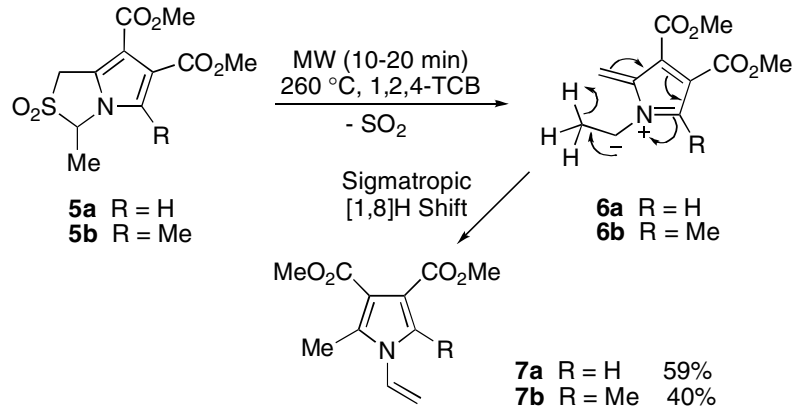<smiles>COC(=O)c1c(C(C)=O)c2n(c1-c1ccccc1)C(c1ccccc1)S(=O)(=O)C2</smiles>

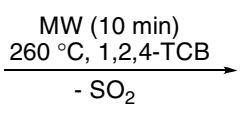<smiles>C=C1C(C(C)=O)=C(C(C)=O)C(=O)N1[C+](C)c1ccccc1</smiles><smiles>COC(=O)c1c(C=Cc2ccccc2)[nH]c(-c2ccccc2)c1C(C)=O</smiles>

$1163 \%$ fact, the generation of azafulvenium methide $\mathbf{6 a}$ in the presence of diethyl diazene-1,2-dicarboxylate allowed the synthesis of the corresponding $[8 \pi+2 \pi]$ cycloadduct $12 \mathbf{a}^{6}$ in $39 \%$ yield, together with the formation of $N$-vinylpyrrole $7 \mathbf{a}$ in $24 \%$ yield. The reaction of sulfone $\mathbf{5 a}$ in the presence of $N$-phenylmaleimide gave $5,6,7,8$ tetrahydroindolizine derivative $\mathbf{1 3 a}$ in $39 \%$ yield. Attempts to promote the $[8 \pi+2 \pi]$ cycloaddition of $\mathbf{6 a}$ with bis(trimethylsilyl)acetylene and with $N$-benzylidenebenzenesulfonamide ${ }^{7}$ led only to the isolation of $\mathrm{N}$-vinylpyrrole 7a. However, the generation of azafulvenium methide $\mathbf{6 a}$ under microwave irradiation in the presence of DMAD afforded a mixture of 3,5-dimethylindolizine1,2,6,7-tetracarboxylate $\mathbf{1 4 a}$ and dihydroindolizine-1,2,6,7-tetracarboxylates (15a and 16) in $17 \%$ overall yield and also $N$-vinylpyrrole $\mathbf{7 a}$ in $16 \%$ yield. Azafulvenium methide $\mathbf{6 b}$, generated from 3-methyl-2,2-dioxo-1H,3H-pyrrolo[1,2-c]thiazole $\mathbf{5 b}$, reacted with diethyl diazene-1,2-dicarboxylate and $N$-phenylmaleimide giving 4,6-dimethyl-1,2,3,4-tetrahydro-pyrrolo[1,2-d][1,2,4] triazine-2,3, 7,8-tetracarboxylate 12b (6\%) and hexahydro-pyrrolo[3,4-f]indolizine $\mathbf{1 3 b}^{8}(30 \%)$, respectively. In both cases, $N$-vinylpyrrole $\mathbf{7 b}$ was the major product. The 1,7-dipole $\mathbf{6 b}$ did not react with bis(trimethylsilyl)acetylene, DMAD nor with $N$-benzylidenebenzenesulfonamide and only $N$-vinylpyrrole $\mathbf{7 b}$ could be obtained from these attempted reactions.

Azafulvenium methide 6c, generated from 2,2-dioxo- $1 \mathrm{H}, 3 \mathrm{H}$ pyrrolo[1,2-c]thiazole $\mathbf{5 c}$ unsubstituted at C-3, cannot undergo the sigmatropic $[1,8] \mathrm{H}$ shift observed for the 1-methylazafulvenium methides (6a and $\mathbf{6 b}$ ). Therefore, in this case there is no competitive formation of $\mathrm{N}$-vinylpyrroles and only 1,7-dipolar cycloadducts are obtained from the microwave-assisted reaction of sulfone $\mathbf{5 c}$ in the presence of dipolarophiles (Scheme 4 ). The reaction of $\mathbf{6 c}$ with diethyl diazene-1,2-dicarboxylate gave $1 \mathrm{H}, 4 \mathrm{H}$-pyrrolo[1,2-d][1,2,4]triazine $\mathbf{1 7}$ in $31 \%$ yield and from the reaction with $N$-phenylmaleimide the hexahydro-pyrrolo[3,4-f]indolizine $\mathbf{1 8}^{9}$ was obtained in $62 \%$ yield. Microwave irradiation of sulfone $\mathbf{5 c}$ for $20 \mathrm{~min}$ in the presence of $\mathrm{N}$-benzylidenebenzenesulfonamide gave the 1,2,3,4-tetrahydro-5 $\mathrm{H}$-pyrrolo[1,2-c]pyrimidine5,6-dicarboxylate $\mathbf{2 0}$ in $31 \%$ yield and the aromatized derivative $\mathbf{1 9}$ in $31 \%$ yield. On the other hand, the microwave irradiation for a longer period $(40 \mathrm{~min})$ allowed the synthesis of dimethyl 7-methyl-3-phenyl-5H-pyrrolo[1,2-c]pyrimidine-5,6-dicarboxylate 19 in $46 \%$ yield as the only product. ${ }^{1} \mathrm{H}$ NMR and ${ }^{13} \mathrm{C}$ NMR data of dimethyl 7-methyl-3-phenylpyrrolo[1,2-c]pyrimidine-5,6-dicar-

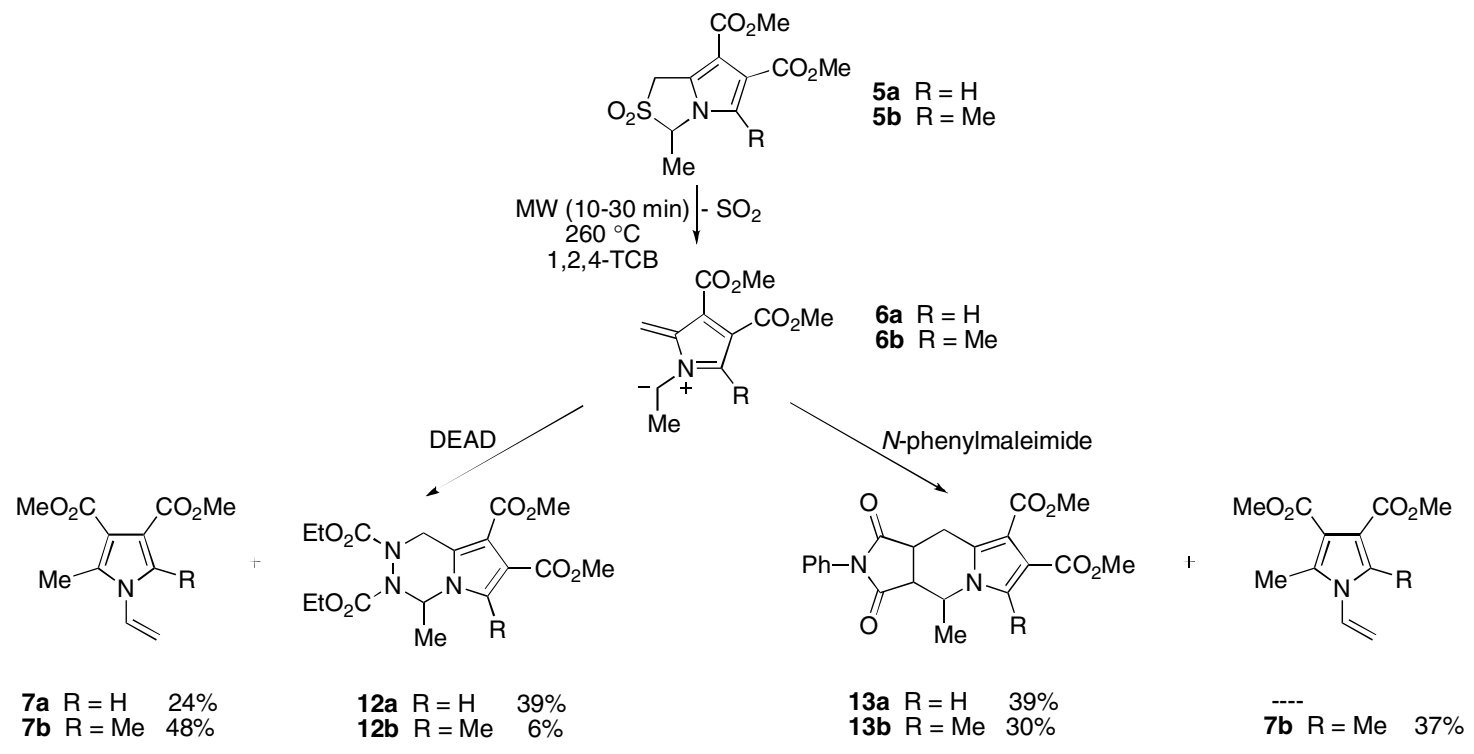

Scheme 3. 


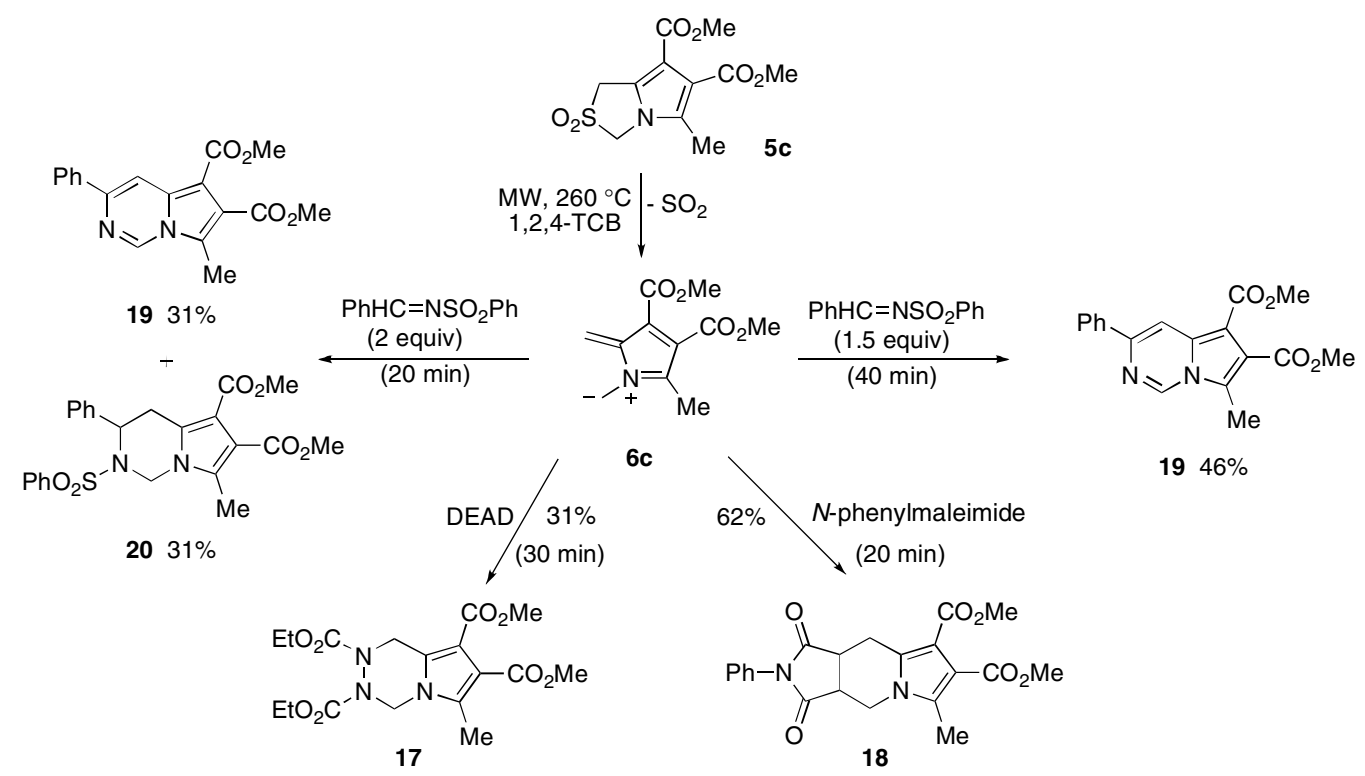

Scheme 4.

boxylate $\mathbf{1 9}$ is collected in Table 1 . The assignment was supported by two-dimensional HMQC and HMBC spectra $(400 \mathrm{MHz})$. In the HMBC spectrum the proton with the chemical shift $8.03 \mathrm{ppm}(\mathrm{H}-$ 4) shows ${ }^{2} J$ coupling constants with C-4a and C-3 with lower intensity. Correlation of $\mathrm{H}-4$ with $\mathrm{C}-8$ is also observed. On the other hand, the proton at $9.54 \mathrm{ppm}(\mathrm{H}-1)$ shows ${ }^{3} \mathrm{~J}$ coupling constants with $\mathrm{C}-4$ and $\mathrm{C}-3$ with higher intensity.

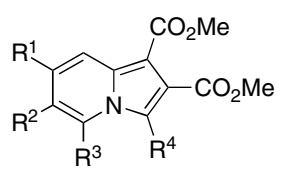

14a $\mathrm{R}^{1}=\mathrm{R}^{2}=\mathrm{CO}_{2} \mathrm{Me} ; \mathrm{R}^{3}=\mathrm{Me} ; \mathrm{R}^{4}=\mathrm{H}$ 14b $R^{1}=R^{2}=\mathrm{SiMe}_{3} ; \mathrm{R}^{3}=\mathrm{H} ; \mathrm{R}^{4}=\mathrm{Me}$<smiles>[R]C1=C([R])Cn2c([10B])c(C(=O)OC)c(C(=O)OC)c2C1</smiles>

15a $R^{1}=R^{2}=\mathrm{CO}_{2} \mathrm{Me} ; \mathrm{R}^{3}=\mathrm{Me} ; \mathrm{R}^{4}=\mathrm{H}$ 15b $R^{1}=R^{2}=\mathrm{SiMe}_{3} ; R^{3}=H ; R^{4}=M e$<smiles>COC(=O)c1cn2c(C(=O)OC)c1C=C(C(C)=O)C2C(C)C(C)=O</smiles>

Attempts to carry out cycloaddition reactions of $\mathbf{6 c}$ with DMAD were not successful. However, azafulvenium methide $\mathbf{6 c}$ reacts with the electron-rich dipolarophile bis(trimethylsilyl)acetylene giving dimethyl 3-methyl-6,7-bis(trimethylsilyl)indolizine-1,2dicarboxylate 14b (8\%) and dimethyl 3-methyl-6,7-bis(trimethylsilyl)-5,8-dihydroindolizine-1,2-dicarboxylate 15b (15\%). Although in low yields the formation of these products proves that the cycloaddition of azafulvenium methide $\mathbf{6 c}$ is not limited to the reaction with electron-deficient dipolarophiles. This is a reactivity pattern also observed for the diazafulvenium methide 4,5-dicarboxylate, unsubstituted at $\mathrm{C}-1$ and $\mathrm{C}-7$. $^{2 \mathrm{~b}}$
Table 1

${ }^{1} \mathrm{H}$ NMR and ${ }^{13} \mathrm{C}$ NMR data for pyrrolo[1,2-c]pyrimidine $\mathbf{1 9}$<smiles>Cc1nc(-c2ccccc2)cc2c(C(=O)O[Na])c(C#N)c(C)n12</smiles>

\begin{tabular}{llc}
\hline $\mathrm{C}$ & ${ }^{1} \mathrm{H}(\mathrm{ppm})$ & ${ }^{13} \mathrm{C}(\mathrm{ppm})$ \\
\hline $\mathrm{C}-14$ & 2.62 & 9.92 \\
$\mathrm{C}-16$ & 3.95 & 51.91 \\
$\mathrm{C}-18$ & 3.97 & 52.68 \\
$\mathrm{C}-4$ & 8.03 & 111.35 \\
$\mathrm{C}-6$ & - & 121.66 \\
$\mathrm{C}-7$ & - & 124.73 \\
$\mathrm{C}-4 \mathrm{a}$ & - & 127.38 \\
$\mathrm{C}-8$ & - & 132.82 \\
$\mathrm{C}-3$ & - & 141.90 \\
$\mathrm{C}-1$ & 9.54 & 145.95 \\
$\mathrm{C}-17$ & - & 163.32 \\
$\mathrm{C}-15$ & - & 165.80 \\
\hline
\end{tabular}

The study was extended to the reactivity of diazafulvenium methide 22 generated from 2,2-dioxo-1H,3H-pyrazolo[1,5-c]$[1,3]$ thiazole $\mathbf{2 1}^{2}$ under microwave irradiation in the presence of dipolarophiles (Table 2 ). We have previously reported that diazafulvenium methide 22 participates in $[8 \pi+2 \pi]$ cycloaddition with a range of electron-deficient dipolarophiles giving pyrazolo[1,5-a]pyridine derivatives (e.g., compounds 23-31). ${ }^{2 \mathrm{c}}$ It has also been reported that the $\mathrm{SO}_{2}$ extrusion of 2,2-dioxo- $1 \mathrm{H}, 3 \mathrm{H}$-pyrazolo[1,5-c]thiazoles occurs more readily than from the analogous pyrrolo sulfones and can be carried out in refluxing 1,2,4trichlorobenzene. ${ }^{2,3}$ This observation was corroborated in this study since the generation of the diazafulvenium methide $\mathbf{2 2}$ under microwaves required lower temperature $\left(230^{\circ} \mathrm{C}\right)$ than the one required to form the azafulvenium methide derivatives $\left(260^{\circ} \mathrm{C}\right)$.

Diazafulvenium methide 22 reacts with DMAD to give a mixture of dihydropyrazolo[1,5-a]pyridines (23 and 24) in 81\% overall yield. On the other hand, the $[8 \pi+2 \pi]$ cycloaddition with methyl propiolate affords regioisomers 26 (23\%) and 27 (28\%) together 
Table 2

Generation and $[8 \pi+2 \pi]$ cycloaddition of diazafulvenium methide $\mathbf{2 2}$

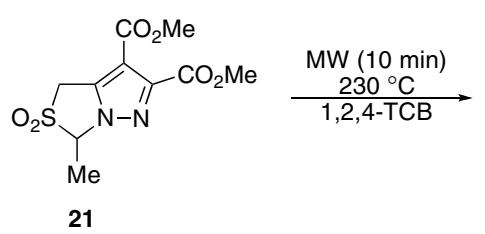

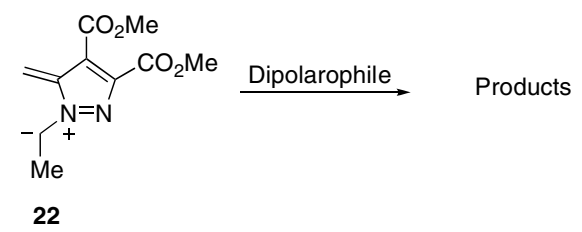

Dipolarophile Products

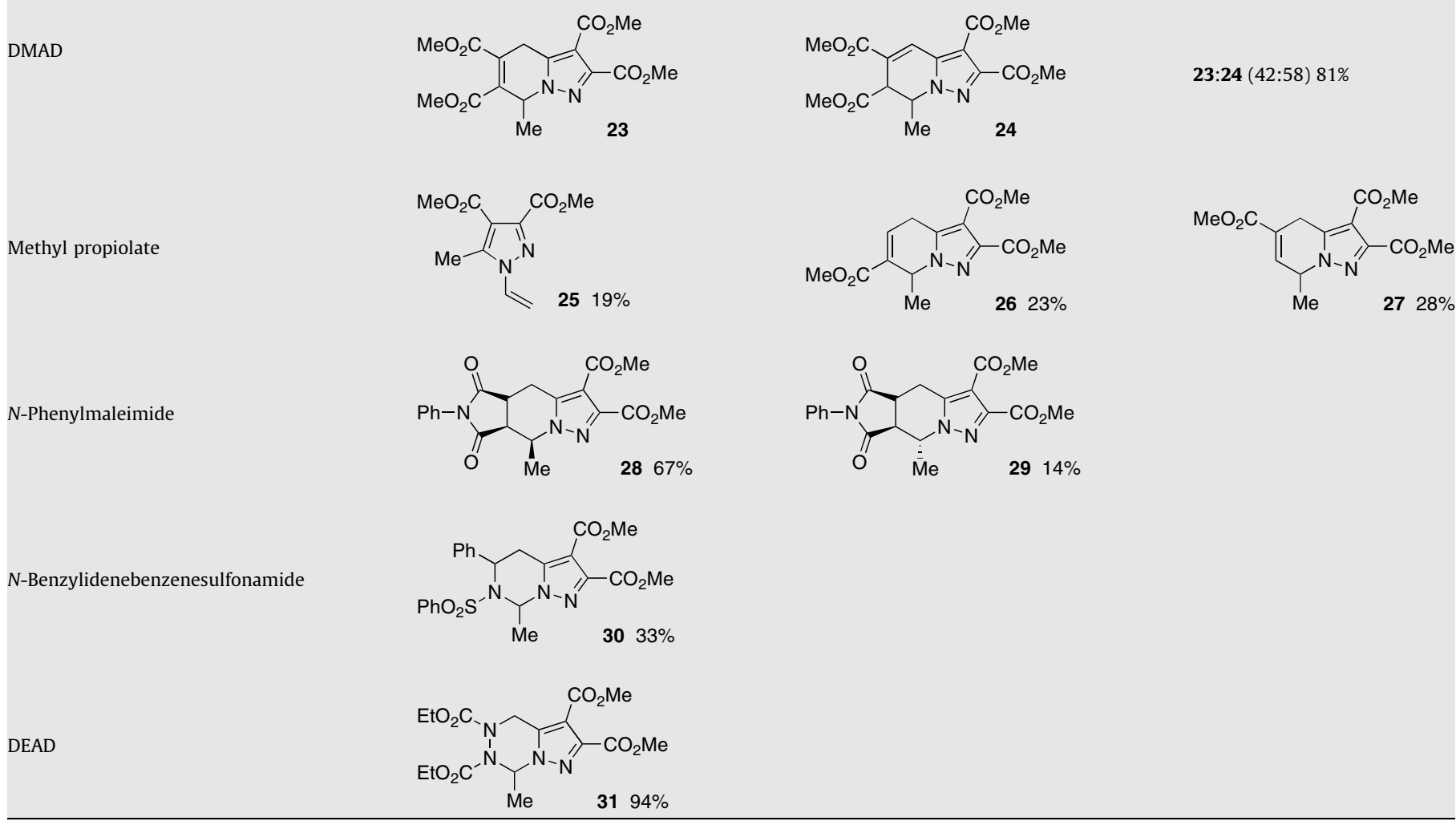

with the formation of $\mathrm{N}$-vinylpyrazole $\mathbf{2 5}$ (19\%) resulting from the sigmatropic $[1,8] \mathrm{H}$ shift of diazafulvenium methide $\mathbf{2 2}$. The 1,7-dipolar cycloaddition of 1,2-diazafulvenium methide 22 with $\mathrm{N}$-phenylmaleimide gave two diastereoisomeric products, cycloadducts 28 (67\%) and 29 (14\%), resulting from an endo cycloaddition with the involvement of the two possible configurations of azafulvenium methide 22. The lower stability of the configuration having the inward methyl group explains the formation of heterocycle 29 in a lower yield. This is a selectivity similar to the one observed previously carrying out the conventional solution thermolysis of $\mathbf{2 2}^{2 \mathrm{~b}}$ The 1,7-dipole 22 can also be trapped by $[8 \pi+2 \pi]$ cycloaddition with $N$-benzylidenebenzenesulfonamide giving tetrahydropyrazolo[1,5-c]pyrimidine-2,3-dicarboxylate $\mathbf{3 0}$ in $33 \%$ yield. The microwave-assisted reaction of sulfone $\mathbf{2 1}$ with diethyl diazene-1,2-dicarboxylate gives pyrazolo[1,5-d][1,2,4]triazine 31 in high yield (94\%). However, diazafulvenium methide $\mathbf{2 2}$ could not be trapped with bis(trimethylsilyl)acetylene and only $\mathrm{N}$-vinylpyrazole $\mathbf{2 5}$ was isolated.

In conclusion, we report the microwave-assisted generation of azafulvenium methides and diazafulvenium methides from 2,2-dioxo-1H,3H-pyrrolo[1,2-c]thiazoles and 2,2-dioxo- $1 H, 3 H$-pyrazolo[1,5-c]thiazoles, respectively. Under these conditions and in the absence of dipolarophiles azafulvenium methides undergo sigmatropic $[1,8] \mathrm{H}$ shifts or 1,7 -electrocyclization giving $N$-vinyl- or $C$-vinylpyrroles. On the other hand, in the presence of dipolaro- philes the $[8 \pi+2 \pi]$ cycloaddition of azafulvenium methides was observed for the first time leading to the synthesis of a range of pyrrole-annulated systems. Diazafulvenium methide generated from dimethyl 3-methyl-2,2-dioxo-1H,3H-pyrazolo[1,5-c][1,3]thiazole-6,7-dicarboxylate under microwaves in the presence of dipolarophiles also participate in $[8 \pi+2 \pi]$ cycloadditions. This is an interesting and useful synthetic strategy to prepare functionalized pyrazole-annulated systems since the reaction time has been reduced from 3 to $4 \mathrm{~h}$ in conventional heating to $10 \mathrm{~min}$.

\section{Acknowledgements}

Thanks are due to FCT (Project PTDC/QUI/64470/2006; Grant SFRH/BPD/26772/2006) and FEDER for financial support. We also acknowledge the Nuclear Magnetic Resonance Laboratory of the Coimbra Chemical Centre (www.nmrccc.uc.pt), University of Coimbra, for obtaining the NMR data.

\section{Supplementary data}

NMR data for compound dimethyl 7-methyl-3-phenylpyrrolo[1,2-c]pyrimidine-5,6-dicarboxylate 19. Supplementary data associated with this article can be found, in the online version, at doi:10.1016/j.tetlet.2008.06.013. 


\section{References and notes}

1. (a) Pinho e Melo, T. M. V. D.; Soares, M. I. L.; Rocha Gonsalves, A. M. d'A.; McNab, H. Tetrahedron Lett. 2004, 45, 3889-3893; (b) Pinho e Melo, T. M. V. D.; Soares, Maria I. L.; Rocha Gonsalves, A. M. d'A.; Paixão, J. A.; Matos Beja, A.; Ramos Silva M. J. Org. Chem. 2005, 70, 6629-6638; (c) Pinho e Melo, T. M. V. D.; Soares, M. I. L.; Nunes, C. M. Tetrahedron 2007, 63, 1833-1841.

2. (a) Pinho e Melo, T. M. V. D.; Soares, M. I. L.; Rocha Gonsalves, A. M. d'A. Tetrahedron Lett. 2006, 47, 791-794; (b) Pinho e Melo, T. M. V. D.; Soares, M. I. L. Nunes, C. M.; Paixão, J. A.; Matos Beja, A.; Ramos Silva, M. J. Org. Chem. 2007, 72 4406-4415; (c) General procedure for [8+2] cycloadditions of diazafulvenium methide 22 under conventional heating. A suspension of 2,2-dioxo- $1 \mathrm{H}, 3 \mathrm{H}$ pyrazolo[1,5-c][1,3]thiazole-6,7-dicarboxylate $\quad \mathbf{2 1}(0.87 \mathrm{mmol})$ and dipolarophile $(1.74 \mathrm{mmol})$ in $1,2,4$-trichlorobenzene $(2.5 \mathrm{~mL})$ was heated at reflux under dry nitrogen for $3-4 \mathrm{~h}$. After cooling to room temperature, the mixture was purified by flash chromatography [hexane] to remove $1,2,4-$ trichlorobenzene followed by elution with ethyl acetate-hexane.

3. (a) Sutcliffe, O. B.; Storr, R. C.; Gilchrist, T. L.; Rafferty, P.; Crew, A. P. A. Chem. Commun. 2000, 675-676; (b) Sutcliffe, O. B.; Storr, R. C.; Gilchrist, T. L.; Rafferty, P. J. Chem. Soc., Perkin Trans. 1 2001, 1795-1806.

4. (a) Lindström, P.; Tierney, J.; Wathey, B.; Westman, J. Tetrahedron 2001, 57, 9225-9283; (b) Kappe, C. O. Angew. Chem., Int. Ed. 2004, 43, 62506284.

5. General procedure for $[8 \pi+2 \pi]$ cycloadditions of azafulvenium methides. A suspension of 2,2-dioxo- $1 H$-pyrrolo[1,2-c]thiazole-6,7-dicarboxylate $(0.5$ $\mathrm{mmol}$ ) and dipolarophile (2-4 equiv) in 1,2,4-trichlorobenzene $(1 \mathrm{~mL})$ was irradiated in the microwave reactor (CEM Focused Synthesis System, Discove S-Class) with the temperature set to $260{ }^{\circ} \mathrm{C}$ for the time indicated in each case. After cooling to room temperature, the mixture was purified by flash chromatography [hexane] to remove 1,2,4-trichlorobenzene followed by elution with ethyl acetate-hexane.

6. 2,3-Diethyl 7,8-dimethyl 4-methyl-1H,4H-pyrrolo[1,2-d][1,2,4]triazine-2,3,7,8tetracarboxylate 12a. Yellowish oil. IR (film) 1735, 1696, 1400, $1215 \mathrm{~cm}^{-1} \cdot{ }^{1} \mathrm{H}$ NMR $\left(\mathrm{CDCl}_{3}, 300 \mathrm{MHz}\right): 1.26-1.35(6 \mathrm{H}, \mathrm{m}), 1.62-1.73(3 \mathrm{H}, \mathrm{m}), 3.82(3 \mathrm{H}, \mathrm{s}), 3.84$ $(3 \mathrm{H}, \mathrm{s}), 4.17-4.27(4 \mathrm{H}, \mathrm{m}), 5.28-5.41(1 \mathrm{H}, \mathrm{m}), 6.28(1 \mathrm{H}, \mathrm{br} \mathrm{s}), 6.54(1 \mathrm{H}, \mathrm{br} \mathrm{s}), 7.16$ $(1 \mathrm{H}, \mathrm{s}) ;{ }^{13} \mathrm{C} \mathrm{NMR}\left(\mathrm{CDCl}_{3}, 75.5 \mathrm{MHz}\right): 14.3,14.4,14.5,51.5,51.7,62.2,62.8,63.1$, 63.7, 110.5, 116.6, 123.2, 130.0, 154.5, 154.9, 163.6, 163.8; MS (EI) $397\left(\mathrm{M}^{+}\right.$ 21\%), 365 (100), 251 (45), 221 (24), 209 (23), 196 (26), 177 (40),164 (35) and 147 (20). HRMS (EI) $m / z 397.1488\left(\mathrm{C}_{17} \mathrm{H}_{23} \mathrm{~N}_{3} \mathrm{O}_{8}\left[\mathrm{M}^{+}\right], 397.1485\right)$.

7. Vishwakarma, L. C.; Stringer, O. D.; Davis, F. A. Org. Synth. 1993, Coll.Vol. VIII, 546-550.

8. Dimethyl 4,6-dimethyl-1,3-dioxo-2-phenyl-2,3,3a,4,9,9a-hexahydro-1H-pyrrolo[3,4-f]indolizine-7,8-dicarboxylate 13b. Brown foam. IR (KBr) 1707, 1393, $1187 \mathrm{~cm}^{-1} .{ }^{1} \mathrm{H}$ NMR $\left(\mathrm{CDCl}_{3}, 300 \mathrm{MHz}\right): 1.49(3 \mathrm{H}, \mathrm{d}, J=7.2 \mathrm{~Hz}), 2.35(3 \mathrm{H}, \mathrm{s})$, $3.11(1 \mathrm{H}, \mathrm{dd}, J=8.6$ and $16.6 \mathrm{~Hz}), 3.38(1 \mathrm{H}, \mathrm{dd}, J=1.1$ and $9.3 \mathrm{~Hz}), 3.51-3.60(1 \mathrm{H}$, $\mathrm{m}), 3.94-3.99(1 \mathrm{H}, \mathrm{m}), 5.01(1 \mathrm{H}, \mathrm{dq}, J=1.0$ and $7.2 \mathrm{~Hz}), 7.01-7.04(2 \mathrm{H}, \mathrm{m}, \mathrm{Ar}-\mathrm{H})$, 7.34-7.42 (3H, m, Ar-H); ${ }^{13} \mathrm{C} \mathrm{NMR}\left(\mathrm{CDCl}_{3}, 75.5 \mathrm{MHz}\right): 10.0,20.4,22.3,36.9,46.0$, $47.7,51.4,51.5,112.2,112.8,126.2,128.8,129.1,129.3,131.2,132.7,164.6$ 165.7, 176.1, 177.2; m/z (EI) $410\left(\mathrm{M}^{+}, 20 \%\right), 378$ (100), 292 (36) and 216 (40). HRMS (EI) $m / z 410.1474\left(\mathrm{C}_{22} \mathrm{H}_{22} \mathrm{~N}_{2} \mathrm{O}_{6}\left[\mathrm{M}^{+}\right], 410.1478\right)$.

9. Dimethyl 6-methyl-1,3-dioxo-2-phenyl-2,3,3a,4,9,9a-hexahydro-1H-pyrrolo[3,4flindolizine-7,8-dicarboxylate 18. Yellowish foam. IR (KBr) 1712,1390 $1212 \mathrm{~cm}^{-1}$. ${ }^{1} \mathrm{H} \mathrm{NMR}\left(\mathrm{CDCl}_{3}, 300 \mathrm{MHz}\right): 2.34(3 \mathrm{H}, \mathrm{s}), 2.95-3.02(1 \mathrm{H}, \mathrm{m}), 3.51-$ $3.52(2 \mathrm{H}, \mathrm{m}), 3.80(6 \mathrm{H}, \mathrm{s}), 3.81-3.94(2 \mathrm{H}, \mathrm{m}), 4.56-4.60(1 \mathrm{H}, \mathrm{m}), 6.96-7.00(2 \mathrm{H}$, $\mathrm{m}, \mathrm{Ar}-\mathrm{H}), 7.37-7.40(3 \mathrm{H}, \mathrm{m}, \mathrm{Ar}-\mathrm{H}) ;{ }^{13} \mathrm{C} \mathrm{NMR}\left(\mathrm{CDCl}_{3}, 75.5 \mathrm{MHz}\right): 10.2,23.1,38.3$, $40.2,41.3,51.5,111.9,112.7,126.3,128.9,129.2,130.9,131.2,133.2,164.5$ 165.6, 176.0, 176.8; $\mathrm{m} / \mathrm{z}(\mathrm{EI}) 396\left(\mathrm{M}^{+}, 22 \%\right), 364(100), 278(28), 217(24)$ and 131 (11). HRMS (EI) $m / z 396.1324\left(\mathrm{C}_{21} \mathrm{H}_{20} \mathrm{~N}_{2} \mathrm{O}_{6}\left[\mathrm{M}^{+}\right], 396.1321\right)$. 